Англійська мова

English language
ISSN: 2411-6181(on-line); ISSN: 2311-9896 (print)

Current issues of social studies and history of medicine. Joint

Ukrainian-Romanian scientific journal, 2018, №:3(19), P. 32-35

UDK 81'276.6'37:61

DOI 10.24061/2411-6181.3.2018.53

\author{
ДИНАМІКА СЕМАНТИЧНИХ ЗМІН ТЕРМІНОЕЛЕМЕНТІВ \\ У АНГЛІЙСЬКІЙ ФАХОВІЙ МОВІ МЕДИЦИНИ \\ Богдана КАЧАН, Виліна ГРИНЧУК \\ ВДНЗ України „Буковинський державний \\ медичний університет“, Чернівці (Україна) \\ bogdana.kachan@bsmu.edu.ua; vylina.grynchuk@bsmu.edu.ua
}

\author{
DYNAMICS OF SEMANTIC CHANGES OF TERMINOELEMENTS \\ IN ENGLISH PROFESSIONAL LANGUAGE OF MEDICINE \\ Bogdana KACHAN, Vylina GRYNCHUK, \\ Higher State Educational Establishment of Ukraine \\ „Bukovinian State Medical University“, Chernivtsi (Ukraine) \\ Researcher ID: S-7419-2016, I-7328-2018 \\ ORCID iD: 0000-0003-4821-8562, 0000-0003-4459-9740
}

\begin{abstract}
Качан Богдана, Гринчук Вилина. Динамика семантических изменений терминоэлементов в английском профессиональном языке медицины. В статье проанализированы семантические изменения терминологических номинаций в английском профессиональном языке медицины. Миграция терминов с одной иноязычной лексико-семантической системы в другую, расширения и сужения значения терминологической единицы формируют необходимость в детализированном анализе такой динамике семантических изменений. Научная новизна статьи заключается в том, что описания семантических изменений медицинских терминов представлено как проблему в формате переводоведения. Выводы. Характерными признаками динамики семантических изменений терминологических номинаций в англоязыческом медицинском дискурсе являются омонимия, полисемия, метафора и метафорический перенос, пейорация, генерализация, специализация, амелиорация, которые демонстрируют необходимость бдительности для переводчика вовремя роботы с текстами медицинского направления.
\end{abstract}

Ключевые слова: медицинский дискурс, терминологическая единица, семантические изменения, омонимия, полисемия, метафора.

A problem and its connection with important scientific tasks. A technological progress accelerates not only the development of a different branch of human activity, but also the improvement of medical science. Innovative inventions, successful research results extend the boundaries of human knowledge of the medical area, which also requires nominations as already gained achievements of medical science and achievements in general. The appearance of new terminoelements cause both the expansion and change of a language lexical layer itself. A migration of termunits plays an important role in the enrichment of the language thesaurus.

Medical terminology of English extends the range of its functioning, and the technological process makes the interaction of various terminology systems, due to which the semantic field of the lexical units of the professional language of medicine expands or narrows. Therefore, the study of the regularities of terminological vocabulary, its formation, dynamics of semantic changes becomes one of the most important tasks of modern science of terms and Linguistics. Notable qualitative and quantitative changes within a termsystem promote the interaction of term fund ${ }^{1}$.

Industry subsystem of terminology vocabulary are formed and develop not separately from one other but closely to each one, each sublanguage reflects and feels the impact of another one, which leads to complications of forms of communication, the emergence of new terms and various structures as a result of mutual enrichment. All of this increases their internal activity, causes the migration of terminology units both in lexico-seman-tic system of one language and among industry termsyste, ms of different languages.

Analysis of recent studies which has a problem solve. In the rapid technological process condition as well as development of medicine as a science, the growth of interest in medical discourse is observed in Linguistics.

Among the scientific research that are dedicated to these issues of terminology, the authors ' work play a significant role which study lexical structure, how to create terms (A.V. Botsman ${ }^{2}$, O.B. Petrova ${ }^{3}$ ), formation and functioning of foreign language (V. Labov ${ }^{4}$ ) and etymology (S. V. Vostrov ${ }^{5}$ ).

\footnotetext{
${ }^{1}$ Kosenko A.V. «Osnovni kharakterystyky anglijskoji meduchnoji terminologiji» [Basic characteristics of the English medical terminology], Naukovyj visnuk humanitarnogo universytetu, Ser.: Filologija [Scientific Herald of the Humanitarian University], 2015, N 18, T. 2, P. 68-70 [In Ukrainian].

${ }^{2}$ Botsman A.V. Strukturno-semantychni ta prahmatychni osoblyvosti farmatsevtychnykh tekstiv (na materiali anhlomovnykh instruktsiy do vzhyvannya likars'kykh preparativ) [Structural-semantic and pragmatic features of the pharmaceutical texts (based on the English instructions for use of drugs)] : Extended abstract of candidate's thesis, K., 2006, 20 p. [in Ukrainian].

${ }^{3}$ Petrova O.B. Strukturno-semantychna kharakterystyka medychnoyi terminolohiyi ta narodnykh naymenuvan' khvorob v ukrayins'kiy movi [Structural-semantic characteristics of medical terminology and national titles diseases in Ukrainian]: Extended abstract of candidate's thesis, Kharkiv, 1994, 24 p. [in Ukrainian].

${ }^{4}$ Labov W. Sociolinguistic Patterns, Philadelphia:Univ. of Pennsylvania Press, 1972, 344 p. [in English].

${ }^{5}$ Vostrova S.V. Linhvokohnityvni ta komunikatyvno-prahmatychni osoblyvosti suchasnoho anhlomovnoho medychnoho dyskursu (na materiali medychnykh testiv z problematyky VIL/SNIDu) [Linguocognitive and communicative-pragmatic features of modern English-language medical discourse (based on medical tests on HIV / AIDS)] : Extended abstract of candidate's thesis, K., 2003, 20 p. [in Ukrainian].
} 
The works of L.Y. Zubova ${ }^{6}$, T.G. Kiaka ${ }^{7}$, D.V. Samoilova ${ }^{8}$, K. Gunsch and others are devoted to separate aspects of the study of terminoelements of English professional language.

The phenomenon of semantic change can be seen both in the works of native and foreign linguists (E. A. Volkova ${ }^{9}$, A. A. Potebnya, S. N. Chistochina ${ }^{10}$ ). The study of the terminological layer of medical sublanguage in English medical discourse demonstrates its richness by meaningful terminological units, which are encoded in lexicographic sources., that allows to conclude that the development enantiosemy, polysemy and homonymy is the result of polarization and a change of semantic word boundaries through expansion, contraction or pluralism of terminations ${ }^{11}$.

Actuality of the study is to explore the dynamics of semantic change terminologists in the professional language of medicine in English terminosistemy; the need for a detailed analysis of enlarging or narrowing the meaning of the word, its migrating from one foreign-language lexicalsemantic system to another; a detailed description of these changes as translation problems.

The aim of the study is about detailed analysis of the dynamics of semantic change of terminoelements in medical English discourse and the characteristics of these changes in the format of translation.

The object of the study is the English-language medical discourse, on the basis of which the phenomena of the dynamics of semantic change in the terminology categories are studied.

A source base for the study was the sample (300) of categories of English-language medical popular science discourse.

The main part. A characteristic feature of the medical terminosystem is its variety, which include morphological formations and processes for the healthy human body and with pathology at different stages of their development; diseases and pathology of the human condition; the shape of its course and symptoms, causative agents and carriers; operational access and surgical intervention. A leading role within the specified macroterminosystem belongs to the following subsystems:

anatomical and histological item;

complex of pathomorphological, pathophysiological and clinical terminosystems;

pharmaceutical terminology.

Nowadays linguists discuss about neologisation of medical area and the dynamics of semantic change.
Sokolov V. V. says that English language of medicine and health care is expanding not only due to the nominations of the tools, procedures, diagnoses, types of therapy but also due to root changes in the classic scheme of providing medical services in English-speaking countries. New linguistic nomination appear to indicate the influence of telecommunication technologies in the health care area, organizational restructuring of the medical area, the emergence of new financial factors being used and ethical issues in modern medicine.

Scientific researchers of terminological ambiguity often indicate that the terms are characterized of categorial ambiguity, that is, a logical chain of meanings of the word and it should be noted that the development categorial ambiguity is based on the regular models of meaning transfer when one term refers to different conceptual categories: the phenomenon and process, action and result, action and condition. Analysis of English meaningful medical terms allowed us to identify the following models of categorical definition of ambiguity:

I. The whole and its part:

diet - 1) харчування, 2) дієта.

II. The process is the result of the process:

infiltration - 1) інфільтрація, 2) інфільтрат

III. The Process is the place of the process implementation:

passage-1) проходження, 2) прохід.

IV. The process is the participant of the process:

control-1) контроль, 2) контрольна група.

$\mathrm{V}$. The process is the active substance in the process:

lubrication-1) змазування, 2) змазка.

VI. A pathological condition or disease is a symptom of this:

fever-1) лихоманка, 2) висока температура ${ }^{13}$.

The appearance of new lexical units in the English medical discourse significantly enrich the vocabulary of modern English. One way of enriching lexical layer of English medical sublanguage are considered to be semantic changes of such terminoelements:

transfer (shift) of meaning;

the change of the denotative component (extension of meaning or its generalization) and narrowing (specialization or restriction);

the change of connotative component meaning (degradation or pejoration; amelioration) $)^{14}$.

Specialization - specification, details of the profession, the acquisition of abilities by a person to perform cer-

\footnotetext{
${ }^{6}$ Zubova L. Yu. «K voprosu ob osobennostyakh y trudnostyakh perevoda anhlyyskykh medytsynskykh sokrashchenyy» [To a question about the features of the first difficulties of translation of English medical abbreviations], Vestnyk VHU. Seryya «Lynhvystyka y mezhkul'turnaya kommunykatsyya» [ Herald of VHU. Series «Linguistics and Intercultural Communication»], 2005, 96 p. [in Russian]. ${ }^{7}$ Kyyak T. R. Lynhvystycheskye aspekty termynovedenyya [Linguistic aspects of terminology studies], K. : UMK VO, 1989, 174 p. [in Russian].

${ }^{8}$ Samoylov D. V. O perevode medytsynskoho teksta [About translation of medical text], M. : Yzdat. dom "Praktyka", 2006,148 p. [in Russian].

${ }^{9}$ Volkova E.A. «Semantycheskye yzmenenyia v anhlyiskom yazyke» [Semantic changes in the English language], Humanytarnye $y$ sotsyalnye nauky [Humanities and Social Sciences, 2016, N 1, P. 62 [in Russian].

${ }^{10}$ Chystiukhyna S. N. Mezhotraslevaia polysemyia v termynolohyy sovremennoho anhlyiskoho yazyka [Interdisciplinary polysemy in the terminology of modern English]: Extended abstract of candidate's thesis, M., 2011, 27 p. [in Russian].

${ }^{11}$ Kosenko A.V. «Osnovni kharakterystyky anglijskoji meduchnoji terminologiji» [Basic characteristics of the English medical terminology], Naukovyj visnyk humanitarnogo universytetu, Ser.: Filologija [Scientific Herald of the Humanitarian University], 2015, N 18 , T. 2, P. 68-70 [in Russian].

${ }^{12}$ Kosenko A.V. Osnovni kharakterystyky... op.cit. , P. 68-70 [In Russian].

${ }^{13}$ Volfberh D.M. «Polysemyia y omonymyia v anhlyiskoi medytsynskoi termynolohyy» [Polysemy and homonymy in the English medical terminology], Fylolohycheskye nauky. Voprosy teoryy y praktyky [Philological Sciences. Questions of theory and practice], Tambov: Hramota, 2017, N 3 (69), Ch. 2, P. 74-78 [in Russian].

${ }^{14}$ Volkova. E. A. «Semantycheskye yzmenenyia v anhlyiskom yazyke» [Semantic changes in the English language], Humanytarnye $y$ sotsyalnye nauky [Humanities and Social Sciences], 2016, N 1, P. 62 [in Russian].
} 
tain tasks and responsibilities that have specific features within the profession etc:

eyelid мед.-повіка; побут - $\underline{\text { lid }}$ - кришка, ковпак, покришка

"The eyelids act to protect the anterior surface of the globe from local injury."

The lexical unit lid represents an item, which covers, closes, prevents something from getting foreign bodies into something. However, in narrow specific medical scientific text, the meaning of the denotation is narrowing when adding a lexical unit eye and means "eyelid" - "повіка".

Generalization - the process of selection and synthesis of the qualitative and quantitative characteristics. The purpose of generalization is to select the main typical features and peculiarities of the object. Generalization allows you to solve minor details, and to emphasize the more significant elements:

Angina - an archaic meaning - "choking pain" (Angina pectoris - грудна жаба), the lexeme now has a modern meaning to denote diseases of the throat and mouth and heart, which makes breathing difficult.

Pajoration - quality-valued reduction of characteristics of the denotation, where negative features are shown:

cancer - 1) біол. рак; 2) знак зодіаку; 3) мед. онкозахворювання

The denotative meaning of the word gave its place to the connotative one, a quality-valued characteristics of which has acquired a pejorative connotation. A cogntive lexical unit is associated with connotative meaning of the word as a medical term.

Amelioration - transfer of the word meaning to a better positive effect or positive shadow of the word meaning :

drug 1) наркотики; мед. - ліки

"You may take a drug yourself, or a healthcare provider may give it to you. Drugs can be dangerous, though, even when they're meant to improve our health." 15

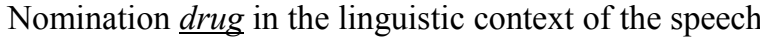
unit transmits narrow semantic meaning of a word, qualityvalued characteristics of which show a positive meaning. It cognitively represents a mean that helps to recover.

A metaphor plays a significant role in the formation of new medical terms, which is widely used in various branches of medicine. Metaphor is the transference of the word with the changed meaning of the root to its shape, or from its shape to shape, or by analogy. The possibility of reconsideration in case of the need of existing lexical units in the language is embodied in the metaphor as a means of creation of a secondary category. To designate a new concept the existing lexical units in the lexical are used. A lexical-semantic method of termcreation is the most productive in terminosystemy, through which the function of a word in the term-metaphor is actualized.

The metaphorical term changes a huge descriptive notation of the concept, since it meets the requirement to be short, which greatly simplifies professional communication and facilitates understanding of a medical phenomenon ${ }^{16}$ :

Christmas factor (coagulation Factor IX (Christmas factor is a protein whose deficiency was first discovered in the 1950s in a little boy by the name of Stephen Christmas. Also known as factor IX, or FIX, it is involved in blood clotting and its deficiency causes the rare form of congenital male hemophilia: hemophilia B. And Coincidences being what they are, the article announcing the discovery of the Christmas factor was actually published in the 1952 Christmas edition of the British Medical Journal!) ${ }^{17}$

Athlete's Foot (Athlete's foot - also called tinea pedis - is a contagious fungal infection that affects the skin on the feet. It can also spread to the toenails and the hands. The fungal infection is called athlete's foot because it's commonly seen in athletes) ${ }^{18}$.

Barber's Itch also known as Sycosis Barbae - Barber's itch is a fungal infection that is sometimes termed, beard ringworm. It normally appears in adult males and can affect the bearded area of the face, including the chin, neck and upper lip. Called Barber's itch because it was spread by infected brushes used for shaving in the Barber's shop ${ }^{19}$.

Cellulite is also known as "Orange peel" or "cottage cheese skin" - Cellulite is a term for the formation of lumps and dimples in the skin. Common names for cellulite are orange peel skin, cottage cheese skin, hail damage, and the mattress phenomenon. Cellulite can affect both men and women, but it is more common in females, due to the different distributions of fat, muscle, and connective tissue ${ }^{20}$.

The dynamics of terminoelements semantic change in the professional language of medicine is indicative of the presence not only of the metaphorical transfers of meaning, but the change of its semantics, which causes certain difficulties in professional communication. Such phenomena are indicative of both polysemy or homonymy of a term ${ }^{21}$.

Terms-homonyms, on the one hand,don't make an understanding of a medical term complicated, if they belong to different terminosystems, but in medical scientific discourse, there are also the terms-homonyms that have different meanings in the study of discourse:

benign - милий, хороший; мед. - доброякісна пухлина

"In most cases, the outlook with benign tumors is very... But benign tumors can be serious if they press on vital structures such as blood vessels or nerves."

blister - надокучлива людина, людина, яка дратує; мед. - пухир

"Blisters are often annoying, painful, or uncomfo But

\footnotetext{
${ }^{15}$ «Medication Administration: Why It's Important to Take Drugs the Right Way», URL:https://www.healthline.com/health/administration-ofmedication (application date 25.05.2018), title from the screen [in English].

${ }^{16}$ Teleky M., Myronyk O. «Metaforychna nominatsiia yak reprezentatsiia medychnoho znannia» [Metaphoric nomination for the representation of medical knowledge], APSNIM [CURRENT ISSUES OF SOCIAL STUDIES AND HISTORY OF MEDICINE], 2018, N 1 (17), P. 34-39 [in Ukrainian].

${ }^{17}$ Brown J.A.C., Chir M. B. Pears pocket medical encyclopaedia, Little : Brown and Company, 2001, P. 133 [in English].

${ }^{18}$ Brown J.A.C., Chir M. B. Pears pocket medical encyclopaedia... op.cit., P. 98 [in English].

${ }^{19}$ Brown J.A.C., Chir M. B. Pears pocket medical encyclopaedia... op.cit., P. 112 [in English].; Vogel A. «What is barber’s itch and how can it be prevented?», URL: https://www.avogel.co.uk/health/skin/fungal-skin-infections/barbers-itch/(application date 25.05.2018), title from the screen [in English].

${ }^{20}$ Crosta P. «Everything you need to know about cellulite», URL: https://www.medicalnewstoday.com/articles/149465.php (application date 25.05.2018), title from the screen [in English].

${ }^{21}$ Hrosheva A.A. «K voprosu ob asymmetryy termynolohycheskoho znaka v medytsynskoi termynolohyy» [Asymmetry of terminological unit in medical terminology], Yzvestyia Samarskoho nauchnoho tsentra Rossyiskoi akademyy nauk [News of Samara Science Center], T. 17, N 2 (2), 2015, P. 449-452 [in Russian].
} 
in most cases, they aren't a symptom of anything serious and will heal without any medical interv

agent - агент; мед. - препарат, носій.

"The new, highly potent strain of botulism, called botulism $H$, is a serious threat, as is any other agent for which there is no treatment. Botulism is on the CDC list, but Ebright believes there needs to be an entire category dedicated to deadly, untreatable biological agents. "

Polisemy of the term is a common linguistic phenomenon which is often found in medical professional language, and can create difficulties in the process of professional communication, especially in scientific research conducted at the border of several scientific fields ${ }^{22}$.

Polysemy must be distinguished from homonymy, since polysemy means language signs that have the same graphic and phonetic structure ${ }^{23}$, but in a different context acquire different meanings, as it helps the addressee to understand the meaning of words in speech units and apply it in communication correctly:

candidate - претендент на певну посаду; мед. учасник медичного дослідження.

chimeric - химерний; мед. - спотворений, гібридний.

examination - оцінювання; мед. - огляд пацієнта (оцінювання стану пацієнта).

smear - мазок (фарби); мед. - мазок для мікроскопічного дослідження.

Conclusion. The characteristic features of the dynamics of terminoelements semantic change in English medical discourse is homonymy, polysemy, metaphor and metaphorical transfer, pejoration, generalization, specialization, amelioration that undergoes dynamic changes in terminological nomination.

The dynamics of semantic changes demonstrate the difficulties of translation during the work of translator with a medical text, requiring a detailed analysis of the lexical layer in the medical discourse.

Качан Б.М., Гринчук В.В. Динаміка семантичних змін терміноелементів у англійській фаховій мові медицини. Мета дослідження полягає у детальному аналізі динаміки семантичних змін терміноелементів англомовного медичного дискурсу та характеристиці цих змін у форматі перекладознавства, зокрема необхідність грунтовного аналізу розширення чи звуження значення слова, його міграції із однієї іншомовної лексико-семантичної системи в іншу; детальний опис цих змін як перекладознавчої проблеми.

Наукова новизна. Медична термінологія англійської мови розширює діапазон свого функціонування, а технологічний процес зумовлює взаємодію різноманітних терміносистем, за рахунок чого розширюється або звужується семантичне поле лексичних одиниць фахової мови медицини. Тому вивчення закономірностей термінологічної лексики, ії утворення, динаміки семантичних змін стає одним із важливих завдань сучасного термінознавства та лінгвістики. Помітні якісні та кількісні зміни у межах терміносистеми сприяють взаємодії термінологічного фонду. Характерними ознаками динаміки семантичних змін терміноелементів у англійському медичному дискурсі є омонімія, полісемія, метафора і метафоричне перенесення, пейорація, генералізація, спеціалізація, амеліорація, які у термінологічній номінації піддаються динамічним змінам. Підсумовуючи все вищезазначене, можна дійти висновку, що семантичні зміни терміноодиниць у англомовному медичному дискурсі демонструють труднощі перекладу під час роботи перекладача 3 текстом медичного спрямування, вимагаючи при цьому детального аналізу лексичного пласту англомовної терміносистеми.

Ключові слова: медичний дискурс, термінологічна одиниця, семантичні зміни, омонімія, полісемія, метафора.

Качан Богдана - викладач кафедри іноземних мов ВНДЗ Украйни «Буковинський державний медичний університет». Коло наукових інтересів: перекладознавство, особливості перекладу німечькомовних медичних текстів украӥнською мовою, методика викладання іноземних мов, геймифікація на заняттях з іноземної мови для студентів медичних ВНЗ. Брала участь у міжнародних та всеукраӥнських проектах та конкурсах (Гете-Інститут, благодійна спілка "Самаритянин", благодійна організачія „Erinnerung, Verantwortung und Zukunft", Німеччина).

Kachan Bogdana is a tutor of the department of foreign languages at the Higher State Educational Establishment of Ukraine „Bukovinian State Medical University“. Scientific interests of the author are the following: translation studies, specific of translation of German medical texts in Ukrainian, methods of teaching foreign languages, gamification at foreign language classes for medical students. The author took part in international and national projects and competitions (Goethe-Institute, ASBvolunteering group, the foundation EVZ (,,Erinnerung, Verantwortung und Zukunft") Germany).

Гринчук Виліна - викладач кафедри іноземних мов ВНДЗ Украӥни «Буковинський державний медичний університет». Коло наукових інтересів: інструменти модернізаиії навчального процесу у вищому навчальному закладі, проблеми викладання іноземних мов у прочесі професійної підготовки спеціалістів у сфері «Медицина», сучасні технології інтерактивного навчання іноземним мовам. Викладач брала участь у численних науково-методичних семінарах, зокрема Global TESOL Ukraine, a також участь у міжнародному з'їзд $i$ «нглійська без кордонів» (Шотландія, Napier University).

Grynchuk Vylina is a tutor of the department of foreign languages at the Higher State Educational Establishment of Ukraine „Bukovinian State Medical University“. Scientific interests of the author are as following: tools for upgrading and modernizing the educational process at the Higher Educational Institution, problems of teaching foreign languages in the process of professional training of specialists in the field of «Medicine», modern technologies of interactive learning of foreign languages. The tutor took part in big number of both scientific and methodological seminars, besides Global TESOL Ukraine as well as in the international conference "English without borders», (Scotland, Napier |University)

\section{Received: 03.06 .2018}

Advance Access Published: August, 2018

(C) B. Kachan, V. Grynchuk, 2018

\footnotetext{
${ }^{22}$ Chystiukhyna S.N. Mezhotraslevaia polysemyia v termynolohyy sovremennoho anhlyiskoho yazyka [Interdisciplinary polysemy in the terminology of modern English] : Extended abstract of candidate's thesis, M., 2011, 27 p. [in Russian].; Volfberh D.M. «Polysemyia y omonymyia v anhlyiskoi medytsynskoi termynolohyy» [Polysemy and homonymy in the English medical terminology], Fylolohycheskye nauky. Voprosy teoryy y praktyky [Philological Sciences. Questions of theory and practice], Tambov: Hramota, 2017, N 3 (69), Ch. 2, P. 74-78 [in Russian].

${ }^{23}$ Volfberh D.M. «Polysemyia y omonymyia v anhlyiskoi medytsynskoi termynolohyy» [Polysemy and homonymy in the English medical terminology], Fylolohycheskye nauky. Voprosy teoryy y praktyky [Philological Sciences. Questions of theory and practice], Tambov: Hramota, 2017, N 3 (69), Ch. 2, P. 74-78 [in Russian].
} 